\title{
ICT Literacy Competence of Staff members of Colleges of Education in Kano State, Nigeria
}

\author{
Isaac Olugbemiga Ogunleye, $\mathrm{PhD}$ \\ Department of Business Education, Federal College of Education, PMB 3045, Kano, Nigeria.
}

This research is financed by Tertiary Education Trust Fund (TETFUND), Nigeria

\begin{abstract}
The role ICT in effective teaching and learning activities in tertiary educational institutions across the globe is sine qua none. However, the use of ICT by individuals is dependent on ICT literacy/competence level. Therefore, this study examined the ICT competence level of staff members in colleges of education in Kano state of Nigeria. A cross-sectional form of descriptive survey design was adopted. Though the population of this study was 2,815 comprising 1,131 and 1,684 academic and non-academic staff respectively a sample of 250 was used. A combination of simple random and stratified random sampling techniques was used to select sample for this study and data was collected through a self-completion structured questionnaire. Student-test statistic was used to test the main alternate hypothesis of the study at 95 per cent confidence level. Generally, data analysis revealed that staff members have high level of ICT competence level in word/data processing, sending/receiving e-messages, sourcing research materials and disseminating information. Staff members have very weak ICT competence level in graphic design, architectural drawings, composing music, processing staff payroll, among others. Significant difference exists between the ICT competence levels of academic and non-teaching (administrative staff). It was recommended, among others, that technological friendly environment should be created and sustained by school administrators. Employees' basic technology needs must be met and sufficient support provided for academics and non-academics to feel comfortable with using technology in their daily official work.
\end{abstract}

Keywords: $\quad$ ICT competence, educational institutions, staff members, adoption, IT diffusion, innovations

DOI: $10.7176 / \mathrm{IKM} / 9-2-08$

\section{Introduction}

With the rapid development of information and computer technologies we are more and more frequently faced with the term ICT literacy and the broader concept of information literacy, which represent the fundamentals for modern society development. It is difficult to predict what will be the direction of development in the future, but it is certain that we will have to adapt and learn new things brought by new technologies. The development of new technologies results in a requirement for improvement of new human capacities. Different social and technological discoveries redesign almost every aspect of human life, generating the need for new literacies such as - Information and Communication Technology (ICT) literacy, digital literacy, computer literacy, technological literacy, media literacy, information literacy, and others (Ivankovic, et al 2013; Amua-Sekyi \& Asare, 2016) .

The basic ICT knowledge and skills that an ICT literate person should own are constantly being challenged and complemented by new technologies and software. Thus, people need to improve themselves to follow the rapid development of information and communication technologies. In educational institutions, this basic knowledge and evolving technologies/software should be included into the courses and the curricula of all the studies. The overall goal of acquisition of ICT by an organization is to meet the goals and objectives of such an organization and invariably improve its productivity and image. Similarly, in order to remain relevant in the current information age, lecturers and students have to adopt ICT to enhance their teaching, learning and research activities. The use of such technologies by the staff is however, dependent on awareness, skills, willingness, ability to use and ease of use of such technologies. Thus, this study set out to assess the ICT competence level of staff members in colleges of education in Kano state of Nigeria. In this study, staff members of the selected institutions were taken to include teaching and non-teaching staff. Also, consideration of ICT was delimited to computer (PC and laptop) and hand-held mobile phones. Information Technology competence was delimited to satisfactory ability/skill to use these devices for administrative and all academic activities including teaching and research. 


\subsection{Justification/Significance of the Study}

The level of ICT skills one possesses may affect the use of ICT and some studies have been carried out to investigate the relationship between ICT skills and ICT use. High use of ICT by staff may be affected by lack of adequate experience. Manda and Mukangara (2007) corroborated the relevance of necessary ICT skills to improve ICT use in a study carried out on use of electronic resources in academic and research institutions in Tanzania and found that poor skills affected use of e-resources. Studies such as Ngorgo (2012), Oguche (2014) and Nkamnebe, Okeke, Udem \& Nkamnebe (2015) have shown that there is still a gap between literacy and competence among staff in Nigerian educational institutions which calls for attention. The above notwithstanding, scanty literature exists only in the area of ICT adoption in Nigerian universities while other categories of education in Nigeria tertiary institutions (such as Colleges of Education) lack empirical studies on the level of ICT competence by staff members. Therefore, this study was embarked upon to assess the level of ICT competence by staff members in Colleges of Education in Kano state of Nigeria.

Educational institutions are globally acknowledged as the citadel of learning, and the arrival of ICT is constantly shaping the means, direction and contents of teaching and learning in ivory towers. Therefore, it is assumed that findings from this study would possibly contribute to filling the observed knowledge gap in this area. Additionally, findings will serve as inputs into Federal Government's policy on IT for tertiary educational institutions. Presence or otherwise of significant difference in ICT competence level between academic and administrative staff members will be established. Findings of this study would thus enable school administrators have an understanding of the patterns of ICT competence level between teaching and non-teaching staff. Therefore, educational planners and administrators would certainly benefit from the findings of this study vis-àvis ICT literacy curriculum planning and implementation.

\subsection{Objectives of the Study}

The primary objective of this study was to assess the level of ICT competence of staff members in colleges of education in Kano state, Nigeria. The study also sought to examine the difference in ICT competence level between academic and non-academic staff.

\subsection{Research Question}

This study was guided by the following questions and all subsequent activities were geared towards providing empirical explanations to the questions.

(i) What is the ICT competence level of staff in colleges of education?

(ii) What difference, if any, exists in the ICT competence level between academic and non-academic staff members?

\subsection{Research Hypothesis}

The following alternate hypothesis was tested at $95 \%$ confidence level:

$\mathrm{H}_{1}$ : There is significant difference in ICT competence level between academic and non-academic staff of colleges of education.

\section{Literature Review}

\subsection{Models of Innovation Adoption}

Research on IT diffusion and adoption has long converged on a core set of theoretical models that seek to explain target adopter attitudes and their innovation-related behaviour (Gallivan, 2001). The core models are: stages of innovation adoption (Becker and Whisler, 1967), the theory of reasoned action (Ajzen and Fishbein, 1980), the theory of planned behaviour (Ajzen, 1985), diffusion of innovations (Rogers, 1985), the technology acceptance model (Davis, 1989), the IT innovation adoption research model (Agarwal and Prasad, 1998) and innovation adoption and implementation (Gallivan, 2001).

Researchers and practitioners have defined innovation in different ways, at times applying the innovation label to phenomena that involve radically different management styles and structures. One source of concern in the study of innovation deals with the scope of the behaviours that constitute an innovation. Another common debate concerning the definition of innovation is whether innovation should be regarded as a process or a discrete event. One authority views innovation as creative processes involving the application of existing ideas to creating a unique solution to a problem (Duncan, 1992).

For proponents of process definition of innovation there are several issues of interest. These include the role of 
communication in facilitating successful innovation, best practices in terms of sequencing the stages of innovation, the characteristics of individuals and teams in successful and unsuccessful processes, and the nature of relationships between parties involved in the innovation process (Gopalakrishman and Damanpour, 2012). Advocates of innovation as an event do not necessarily ignore the processes involved in innovation. Within the context of this research, both the process approach and the discrete event perspective have merit and are therefore relevant, as adopters may be differentiated from non-adopters.

From the process perspective, the issue of concern is the adoption stage or phase of implementation that ultimately spells success or failure for subsequent phases of the adoption and of the innovation itself. The use of the discrete event approach is fitting for assessing the merits of particular organizational structures and business strategies in the adoption of innovation. Damanpour (2011) reminds enthusiasts of this approach that in practice, inventor organizations often seek to develop new process of outputs as ends in themselves, choosing to refrain from commercial uses of the invention for long periods. It is the view of the researcher that the relationship between invention and strategy would be understood better if one recognizes that many firms achieve sustained competitive advantage not by invention, but by the clever use of existing processes, products or technologies.

\subsection{ICT Literacy and Usage}

The world is changing with the development of technology and information and communication technology in particular. The trend of development is so intensive that we are confronted with the constant increase of new technologies every few years (Ibegwam, 2004). According to Ibegwam (2004) and Adetimirin (2012), it is impossible to predict what will be the direction of development in the future, but it is certain that we will have to adapt and learn new things brought by new technologies. The development of new technologies results in a requirement for improvement of new human capacities. Different social and technological discoveries redesign almost every aspect of human life, generating the need for new literacy skills such as - Information and Communication Technology (ICT) literacy, digital literacy, computer literacy, technological literacy, media literacy, information literacy, and others (Amua-Sekyi and Asare, 2016).

According to The International ICT Literacy Panel (2002), ICT literacy could be defined as the ability to use digital technology, communications tools, and/or networks to access, manage, integrate, evaluate, and create information in order to function in a knowledge society. While the traditional term for literacy meant writing, reading and numeracy, a new term " 21 st century literacy” stands for communication skills, skills of using modern information and communication technology, high-quality understanding of natural and social events, problem solving and informed decision making, skill and ability for teamwork and continuous learning (Mcilroy, Sadler and Boojawon, 2007; Mutula, 2010). The basic ICT knowledge and skills that an ICT literate person should have are constantly evolving and people need to improve themselves to follow the rapid development of information and communication technologies (Adetimirin, 2012; Amua-Sekyi and Asare, 2016). The term computer literacy has long been used to describe human skills and predisposition to use computers and information technologies (Corbett and Willms, 2002; Ibegwam, 2004). The broader use of the concept "ICT competence" has in its roots the need to include as soon as possible technology dimensions contributed by developments such as networks and Internet. Most of these skills, that an individual should acquire to be considered computer literate, are now often considered to be components of more comprehensive concept of ICT competence. In other words, society is becoming more dependent on new technologies and a great deal of attention is being paid to ICT competence which nowadays is equivalent to the importance of reading, writing and numeracy in the 19 th and 20th century.

ICT competence is often taken for granted, to the detriment of lecturers and students who actually lack skills that fall go beyond the scope of ICT literacy. Despite the increased use of ICT for educational and entertainment purposes, there is an assumption about a low level of ICT competence among many staff of tertiary educational institutions (Amua-Sekyi and Asare, 2016). ICT competence focuses on bridging the ideas of information literacy and technology literacy. It is concerned with on how to locate, organize and communicate information with digital environments. Ibegwam (2004) carried out a study on use of the Internet by students of the College of Medicine, University of Lagos, Nigeria and found out all the 200 respondents used the Internet and majority used it for searching academic materials and visiting other university websites.

Users' ICT competence is influenced by variety of factors such as knowledge/awareness of ICT, access to ICT, competence in ICT and a host of other socio-economic variables. Lecturers must have a comfortable level of ICT competence in order to be able integrate ICT as a primary tool for teaching and learning across the curriculum. Lecturers' professional or self-training in the use of technology helps to increase their efficiency in using ICT in education (Manda and Mukangara, 2007; Bingimlas, 2009). 


\section{Methodology}

The plan adopted for this study was a cross-sectional form of descriptive survey design. The population of this study comprised all staff members in the three (03) government owned Colleges of Education in Kano state, Nigeria. Altogether, the population of the study was 2,815 comprising 1,131 and 1,684 academic and nonacademic (administrative) staff respectively. A sample of 250 was adjudged to be representative of the population of this study and according to Bryman (2008), it is the absolute size of a sample that is important and not its relative size, and decisions about sample size represent a compromise between the constraints of time and cost, the need for precision and anticipated non-response rate. A combination of simple random and stratified random sampling techniques was adopted. Staff members were stratified first along their career groupings, that is, the teaching and non-teaching staff (academic vs. non academic staff). The non-teaching staff were further stratified using their job cadre (junior and senior staff categories). Subsequently, simple random sampling technique was used to select sample from each stratum and a sample of 250 was proportionately selected from among the three Colleges of Education.

Data for this study was collected through the use of a self-completion questionnaire measured on a 5-point Likert scale ranging from 5 to 1 . The questionnaire was subjected to both face and content validity and test-retest reliability and internal consistency measures were used in order to ensure reliability of the instrument. The result of test-retest was a coefficient $r=0.88$ and a norm score of 18.07. According to Bryman (2008), a test-retest correlation (r) of 0.80 and above implies an acceptable level of internal reliability (or temporal stability). For the internal consistency, Cronbach's alpha reliability coefficient was computed and all the variables of interest have a reliability score of at least 0.6 and according to Bryman (2008) a coefficient alpha of 0.60 and above would be considered satisfactory for the internal consistency reliability.

Administration of the instrument, which lasted for 4 weeks, was personally done by the researcher and there were follow-up visits for reminder purpose. Consequently, 190 usable copies of the questionnaire were used for data analysis. Descriptive statistics such as frequency distribution (percentages) and standard scores (z-scores) were used to present and analyse data for the research question while the only hypothesis of the study was tested with student t-test inferential statistics at 95 per cent confidence level.

\section{Data Presentation and Discussion}

Based on the objective of the study, it was considered pertinent to ascertain the ICT competence level of the respondents. Hence, they were asked to indicate the extent of their ability to use ICT related devices to perform each one of the listed 17 functions/activities. The summary of their responses is presented in the table 1 below. Analysis revealed that respondents have good ICT competence in 'word processing' ranked first with a z- score of 10.5543. This was followed by good ability to use ICT devices to 'send/receive e-messages' (z-score = 9.9122), 'search for research materials' (8.1836), 'data processing' (6.4312), 'disseminate information' (4.9779) and 'managing students/staff records' (z-score $=2.5108)$ in decreasing order of competence. Also, respondents indicated that they have low level of ICT competence in using computer to 'process exams results' (z-score = $1.6321)$ and 'playing games/entertainment' (1.2604). It was revealed that the respondents have weak ICT competence in 'registration of students' (z-score $=0.8548)$. However, findings equally showed that the respondents have very weak ICT competence in 'typesetting textbooks' (z-score $=-0.9701)$, 'instructional presentation' (-0.7674), 'simulation of experiment' (-0.0474), 'statistical analysis' (-1.6461), 'graphic design ($5.8368)$, etc.

In general, the findings revealed that the respondents have good ICT competence in 6 out of the 17 selected tasks. Thus, finding thus confirmed the discovery of Ogwu, Ogwu and Eyitayo (2010) that fresh undergraduates in University of Botswana had low computer proficiency. In Adetimirin (2012), it was also discovered that undergraduates in selected state universities in Nigeria have poor ICT literacy skills while those students in the selected federal universities have average ICT literacy skills. Additionally, in a study on the ICT literacy level of Philosophy students in University of Mostar, Ivankovic, Spiranec and Miljko (2013) discovered an unsatisfactory level of ICT literacy. However, in Amua-Sekyi and Asare (2016) it was discovered that Ghanaian lecturers are knowledgeable in manipulating the computer and performing ICT tasks such as word processing, communication, web and presentation skills. Earlier studies, Veglis, Tsourvakas, Pomportsis and Avraam (2005) discovered that information technology is being employed quite extensively by Greek local newspapers. Middleberg and Ross (2001) found (i) that the exploitation of Internet services is quite extensive in the U.S., where journalists employ a variety of sources in their search for news items and (ii) that things are changing so rapidly now that the typical newsroom has far more Internet connections than phone lines. 
Table 1: Z-score analysis of Respondents' ICT competence level

\begin{tabular}{llll}
\hline \multicolumn{1}{c}{ ICT Usage areas } & $\begin{array}{l}\text { Sample } \\
\text { mean }\end{array}$ & $\begin{array}{l}\text { Sample } \\
\text { S. D. }\end{array}$ & Z-score \\
\hline word processing & 3.8100 & 1.1225 & 10.5543 \\
data processing & 3.4881 & 1.1646 & 6.4312 \\
typesetting of textbooks & 2.9103 & 1.3598 & -0.9701 \\
statistical analysis & 2.8575 & 1.2369 & -1.6461 \\
Instructional presentation & 2.9261 & 1.2556 & -0.7674 \\
graphic designs & 2.5303 & 1.2955 & -5.8368 \\
architectural drawings & 2.1478 & 1.3311 & -10.7372 \\
Playing games/entertainment & 3.0844 & 1.2800 & 1.2604 \\
managing students/ staff records & 3.1821 & 1.3158 & 2.5108 \\
registration of students & 3.0528 & 1.4057 & 0.8548 \\
processing of exams results & 3.1135 & 1.3571 & 1.6321 \\
dissemination of information & 3.3747 & 1.3101 & 4.9779 \\
processing of staff payroll & 2.4142 & 1.4216 & -7.3238 \\
Composition of music & 2.2058 & 1.3549 & -9.9937 \\
searching for research materials & 3.6253 & 1.3302 & 8.1886 \\
sending/receiving e-messages & 3.7599 & 1.2442 & 9.9122 \\
simulation of experiments & 2.2797 & 1.2852 & -0.0474 \\
Population mean & $\mathbf{2 . 9 8 6 0}$ & & \\
\hline \multicolumn{1}{c}{ Population std. Deviation } & & & $\mathbf{0 . 0 7 8 1}$ \\
\hline
\end{tabular}

$\mathrm{n}=190$

Source: Field Survey (2018)

It was also considered pertinent to ascertain if there is any difference in staff ICT competence level across job designations. Hence, the hypothesis which states that "there is significant difference in ICT competence level between academic and non-academic staff in Colleges of Education" was tested using statistical test of difference between means of independent samples. The summary of the result was presented in table 2 below.

Test for Homogeneity of Variance: A potential problem in t-test statistics is the assumption that samples are obtained from population with equal variances. This means that the variability of scores for each of the groups is similar otherwise the data violates the assumption of equal variance. In this case, Levene's test for equality of variances as produced by SPSS t-test output is examined. However, t-test produces two results: for situations where the assumption is not violated and for when it is violated. The outcome of the Levene's test determines which of the t-values produced by SPSS is the correct one to report. According to Pallant (2001), if the significance value in Levene's test is larger than .05, values in the first line (under equal variances assumed) should be reported and this goes further to suggest that the assumption of equal variance has not been violated. In this study, the significance value of Levene's test is .056 therefore, the assumption of equal variances is not violated and the values given under equal variances assumed are hereby reported (as in table 2 below). 
Table 2: Statistical test of difference between means of ICT competence level of academic and nonacademic staff

\begin{tabular}{||l|c|c|c|c|c|c|c||}
\hline $\begin{array}{c}\text { Perceived GSM } \\
\text { Service Quality }\end{array}$ & N & $\begin{array}{c}\text { Sample } \\
\text { mean }\end{array}$ & $\begin{array}{c}\text { sample } \\
\text { std. dev. }\end{array}$ & t-value & df & sig. & $\begin{array}{c}\text { Eta } \\
\text { Square }\end{array}$ \\
\hline Academic staff & 80 & 3.09 & .432 & \multirow{2}{*}{10.017} & 650 & .025 & .348 \\
\hline Administrative staff & 110 & 2.79 & .382 & & & & \\
\hline
\end{tabular}

Source: Field Survey (2018)

The result presented in table 2 above indicated a t-value of 10.017 which was found to be significant at $p<0.050$ (computed sig. value $=.025$ ). The result thus indicated a significant difference in the mean scores of ICT competence for academic and non-academic staff at $p=0.025$. This means that significant difference exists in the ICT competence level between academic and non-academic staff in Colleges of Education. Thus, the hypothesis was supported by this finding and is thereby upheld. However, it must be stated that ICT competence level of academic staff is higher than of the non-academic staff as depicted by higher sample mean and sample standard deviations values. This finding is at variance with the study of Ugwuanyi (2009) on the ICT literacy among academics in Enugu state, Nigeria where it was revealed that the level of ICT literacy skills among the academics is low but that academics were interested to adopt the current trend of ICT literacy and application in the present day ICT environment.

Sequel to the presence of significant difference in the mean scores of ICT competence level of academic and non-academic staff, an attempt was further made to determine the "effect size" (strength of association) which provides an indication of the magnitude of the difference between the groups (not just whether the difference could have occurred by chance). Therefore, there is need to calculate the "Eta square" in order to ascertain the proportion of variation in the dependent variable that is explained by the independent variable. According to Pallant (2001), the formula for calculating Eta square is given as:

$\mathrm{t}^{2}$

Eta square $=$

$$
\mathrm{t}^{2}+(\mathrm{N} 1+\mathrm{N} 2-2)
$$

$$
10.017^{2}
$$

Eta square $=$

$$
10.017^{2}+(80+110-2)
$$

$$
=0.348
$$

The Eta square of .348 represents a "large effect" and by extension it suggested that the magnitude of the difference in the means was very large. Also, it indicated that 34.8 per cent variation in level of ICT competence is explained by these 17 selected ICT task areas.

\section{Conclusion}

The researcher examined the ICT competence level of staff members of colleges of education in Kano state of Nigeria and from the findings it was concluded that staff members have high level of ICT competence level in word/data processing, sending/receiving e-messages, sourcing research materials and disseminating information. Staff members have very weak ICT competence level in graphic design, architectural drawings, composing music, processing staff payroll, among others. It was also concluded that significant difference exists between the ICT competence levels of academic and non-academic staff. In the same vein, academic staff members have better ICT competence level than the non-academic staff members. 


\section{Recommendations}

In the light of the above findings and conclusions therefrom, it is recommended that technological friendly environment should be created and sustained by school administrators. Employees' basic technology needs must be met and sufficient support provided for academics and non-academics to feel comfortable with using technology in their daily official work. Therefore, institutional heads should consider sales, training and maintenance agreement with hardware producers and software developers for the benefits of staff members.

Sponsorship to attend workshops and seminars in specialized software should be provided for staff members in order to broaden their awareness and expertise of ICT devices as instructional delivery tools. Therefore, academic staff members should be encouraged to deploy ICT facilities in their teaching and research assignments through constant training and retraining. Also, the ICT competence level of non-academic staff members in colleges of education should be enhanced through regular attendance of workshops, seminars and conferences.

\section{References}

Adetimirin, A. E. (2012). “ICT Literacy among undergraduates in Nigerian universities”, Education Information Technology, 17, 381-391.

Agarwal, R. \& Prasad, J. (1998). "The antecedents and consequents of user perceptions in information technology adoption”, Decision Support Systems, 22(1),15-29.

Ajzen, I. \& Fishbein, M. (1980). Understanding Attitudes and Predicting social behaviour, New Jersey: Englewood Cliffs, Prentice Hall.

Amua-Sekyi, E. T. \& Asare, Y. (2016). “A Survey of Information Communication Technology Literacy among Lecturers", Information and Knowledge Management, 6(8), 1-7. (accessed on August, 2018).

Becker, S. N. \& Whisler, T. I. (1967). "The innovative organization: a selective view of current theory and research", The Journal of Business, 40(4), 462-9.

Bryman, A. (2008). Social Research Methods, New York: Oxford University Press Inc.

Corbett, B. \& Willms, J. (2002). "Information and communication technology - access and use", Education Review Quarterly, 8(4), 8-14. (accessed 20 December, 2018).

Damanpour, F. (2011). "Organisational innovation: A metal-analysis of effects of determinants and moderators". Academy of Management Journal, 34(1), 565-90.

Davis, F. D. (1989). "Perceived usefulness, perceived ease of use and user acceptance of information technology". MIS Quarterly, 15(3), 319-40.

Duncan, R. B. (1992). "Characteristics of organizational environments and perceived environmental uncertainty". Administrative Science Quarterly, 17, 313-17.

Gallivan, M. J. (2001). 'Organisational adoption and assimilation of complex technological innovations: development and application of a new framework", The DATABASE for Advances in Information Systems, 32(3), 51.

Gopalakrishman, S. \& Damanpour, F. (2012). "Innovation research in economics, sociology and technology management: a review and synthesis", Proceedings of the Academy of Management, 52(6), 488.

Ibegwam, A. (2004). "Internet access and usage by students of the College of Medicine, University of Lagos". The Information Technologist, 1(1\&2), 81-87.

International ICT Literacy Panel (2002). Digital transformation: A framework for ICT Literacy. Princeton, New Jersey: Educational Testing Service, (accessed 12 August 2018).

Ivankovic, A., Spiranec, S. \& Miljko, D. (2013). "ICT Literacy among the students of Faculty of Philosophy University of Mostar", Procedia -Social and Behaviour Sciences, 93, 684-688. (accessed 20 December, 2018).

Manda, P. A. \& Mukangara, F. (2007). "Gender analysis of electronic information resource use: the case of the University of Dar Es Salaam, Tanzania”, University of Dar Es Salaam Library Journal, 9(1), 31-52. (accessed 29 December, 2018).

Mcilroy, D., Sadler, C. \& Boojawon, N. (2007). "Computer phobia and computer self-efficacy: their association with undergraduates' use of university computer facilities", Computers in Human Behavior, 23(3), 1285-1299. 
(accessed 29 December, 2018).

Middleberg, D. \& Ross, S. (2001). "Seventh Annual Middleberg/Ross Survey of Media in the Wired Word", New York: Middleberg Euro RSCG.

Mutula, S. M. (2010). "Challenges of information illiterate first-year entrants for the University of Botswana", Information Development, 26(1), 79-86. (accessed 29 December, 2018).

Ngorgor, R. (2012). "Information and Communications Technology Literacy skill level of staff of National Library of Nigeria". MLS Thesis, Department of Library and Information Science, University of Nigeria, Nsukka.

Nkamnebe, E., Okeke, I., Udem, O. \& Nkamnebe, C. (2015). "Extent of Information and Communication Technology skills Possessed by librarians in University libraries in Anambra state, Nigeria". Information and Knowledge Management, 5(9), 22-31.

Ogwu, F. J., Ogwu, E. N. \& Eyitayo, O. T. (2010). "Computer proficiency among fresh undergraduate students of the University of Botswana: Implications for learning", Proceedings of the Third IASTED, (accessed 11 December 2018).

Oguche, D. (2014). "Effect of Information and Communication Technologies Literacy Competence on Job Performance of Library Staff in Nigerian Federal University Libraries". MLS Thesis, Department of Library and Information Science, Ahmadu Bello University, Zaria.

Pallant, J. (2001). SPSS Survival Manual: A step by step guide to data analysis using SPSS for Windows. Maidenhead - Berkshire: Open University Press.

Rogers, E. M. (1995). Diffusion of Innovations, $4^{\text {th }}$ edition, New York: The Free Press.

Ugwuanyi, C. (2009). "Information and Communication Technology (ICT) literacy among academic librarians in Enugu State", International Journal of Information and Communication Technology, 6(1), 123 - 132. (accessed 29 December, 2018).

Veglis, A.; Tsourvakas, G.; Pomportsis, A. \& Avraam, E. (2005). “Adoption of information technology by Greek Journalists: A Case study", First Monday, Peer Reviewed Journal on the Internet, 10(8),120-132. 